FOLIA HISTORICA CRACOVIENSIA, 20: 2014, s. 309-317

DOI: http://dx.doi.org/10.15633/fhc.657

Stanisław Tokarz

Uniwersytet Papieski Jana Pawea II w Krakowie

\title{
Klerycy z Administratury Apostolskiej w Czeskim Cieszynie studiujący na Wydziale Teologicznym Cyryla i Metodego w Pradze
}

W ostatnich latach przy okazji omawiania stosunków polsko-czeskich coraz częściej porusza się problem tzw. Zaolzia. Terminem tym określa się część Śląska Cieszyńskiego, która zamieszkana jest przez Polaków i znajduje się na terenie Republiki Czeskiej'. Obszar ten powstał po I wojnie światowej. Śląsk Cieszyński, leżący na pograniczu polsko-czeskim, stał się obszarem spornym, a nawet celem czeskiego najazdu w 1919 roku. Ostatecznie w roku 1920 decyzją Rady Ambasadorów został podzielony między Polskę a Czechosłowację, z granicą wyznaczoną na rzece Olzie ${ }^{2}$, istniejącą obecnie.

Jeszcze bardziej skomplikowana okazała się sytuacja Kościoła katolickiego na tym obszarze. Wchodził on w skład diecezji wrocławskiej, jednak w 1742 roku w wyniku przegranych przez Austrię wojen śląskich większość obszaru metropolii wraz ze swą stolicą znalazła się w Prusach. Niewielki skrawek tzw. Księstwa Cieszyńskiego pozostał w państwie Habsburgów i w roku 1770 utworzono tu Wikariat Generalny austriackiej części diecezji wrocławskiej³. Istniał on 155 lat do 1925 roku, kiedy to jego polska część została włączona do diecezji śląskiej ze stolicą w Katowicach. Po stronie czechosłowackiej nadal pozostał status przejściowy. W roku 1920 utworzono komisariat dla czeskiego Śląska wschodniego ${ }^{4}$. W polskim społeczeństwie w czasie II wojny światowej

${ }^{1}$ G. Gąsior, Zaolzie. W: Zaolzie. Polsko-czeski spór o Ślask Cieszyński 1918-20o8. Warszawa 2008, s. 2.

${ }^{2}$ W. Roszkowski, Najnowsza historia Polski 1914-1945. Warszawa 2003, s. 96.

${ }^{3}$ J. Londzin, Historja Generalnego Wikarjatu w Cieszynie. Cieszyn 1926, s. 5.

${ }^{4}$ Tamże, s. 75. 
i tuż po niej istniało przekonanie, że Zaolzie znajdzie się ponownie w granicach Polski, ponieważ tuż przed wojną, w październiku 1938 roku rejon ten został odzyskany przez władze w Warszawie. Stało się jednak zupełnie inaczej. Teren Śląska Cieszyńskiego na zachód od Olzy ponownie wszedł w skład Czechosłowacji5. W roku 1947 utworzono na tym obszarze Administraturę Apostolską z siedzibą w Czeskim Cieszynie ${ }^{6}$. Zgodnie z Kodeksem prawa kanonicznego z 1917 roku „dla poważnych i specjalnych racji, papież powierza czasem kierowanie diecezją erygowaną kanonicznie, której stolica wakuje lub nie, administratorowi apostolskiemu na stałe lub czasowo"7. W tym przypadku chodziło o wydzielenie $\mathrm{z}$ diecezji wrocławskiej obszaru, który znajdował się w innym państwie niż jej stolica. Jego granice obejmowały większy obszar niż samo Zaolzie, jednak większość terenu Administratury zajmowały ziemie znajdujące się po październiku 1938 roku w Polsce ${ }^{8}$. Ta tymczasowa struktura funkcjonowała do roku 1977, a już od 1978 roku została włączona do arcybiskupstwa w Ołomuńcu9.

Sytuację dodatkowo komplikował fakt, że zmieniało się miejsce kształcenia kandydatów na kapłanów z terenu najpierw Śląska Cieszyńskiego, a następnie Zaolzia. Początkowo klerycy kształcili się w seminarium duchownym w Ołomuńcu. Następnie kardynał Kopp utworzył uczelnię dla przyszłych księży $\mathrm{w}$ Widnawie $^{10}$. W powojennym państwie czechosłowackim sytuacja Kościoła katolickiego wyraźnie się pogorszyła, a komunistyczne władze dokładały wszelkich starań, aby ta tendencja się nie zmieniała. Od roku 1950 działał Wydział Teologiczny Kościoła Rzymskokatolickiego Cyryla i Metodego w Pradze, przeniesiony od 1 października 1953 roku do Litomierzyc w północno-zachodnich Czechach, gdzie funkcjonował do roku 1990. Tam też jeździli kandydaci na księży katolickich z ziem czeskich, czyli archidiecezji praskiej i ołomunieckiej. Kształcili się tam także klerycy pochodzący z terenów wschodniej części archidiecezji wrocławskiej w Czechosłowacji ${ }^{11}$. Przez okres 37 lat przewinęło się

${ }^{5}$ J. Kuś, Szkice z dziejów kościelnych Śląska Cieszyńskiego. Kraków 1983, s. 75.

${ }^{6}$ T. Zbranek, Apoštolský administrátor František Borgiáš Onderek. W: Sborník Státního okresního archivu Frýdek-Místek. Frydek-Mistek 2011, s. 104.

7 Kanon 312 - Codex Iuris Canonici [1917].

${ }^{8}$ J. Kuś, Szkice..., s. 75.

9 S. Balik, J. Hanus, Katolicka Cirkev n Ceskoslovensku 1945-1989. Brno 2007, s. 53.

${ }^{10}$ J. Londzin, Historja..., s. 58.

${ }^{11}$ V. Novotny, Katolicka Teologicka Fakulta 1939-199o. Praha 2007, s. 145-160. 
tam wielu alumnów z obszaru czesko-cieszyńskiej Administratury Apostolskiej, a część z nich została wyświęcona na kapłanów i objęła później swoje placówki.

$\mathrm{W}$ spisach i dokumentach klerycy pochodzący z terenu archidiecezji wrocławskiej byli oznaczani $\mathrm{w}$ różny sposób. W rubryce diecezji pochodzenia wpisywano: Apostolska Administratura Czeski Cieszyn, archidiecezja wrocławska lub nawet diecezja Czeski Cieszyn. Wszystko zmieniło się w roku 1978, kiedy przypisano im metropolię ołomuniecką. W dokumentach dostępnych $\mathrm{w}$ archiwum litomierzyckiego seminarium duchownego nie wpisywano narodowości alumnów. Wśród poniżej opisanych studentów możemy znaleźć tych, którzy nosili tak polsko brzmiące, jak i czeskie nazwiska. Kryterium selekcji dla niniejszego artykułu było tylko i wyłącznie miejsce urodzenia kleryka i jego pochodzenie. Po dokonaniu takiego wyboru okazało się, że przez wyższe seminarium duchowne $\mathrm{w}$ Litomierzycach przeszły łącznie 64 osoby pochodzące z rejonu nas interesującego. Nie wszyscy jednak kształcili się z zamiarem powrotu do miejsca swojego pochodzenia. Kilku z nich miało zostać wyświęconych dla innych diecezji w Czechosłowacji. Nie wszyscy także, którzy zaczynali, ukończyli studia w regulaminowym czasie, niektórzy w ogóle ich nie skończyli. Materiał źródłowy przedstawia dane do roku 1990 włącznie, dlatego nic nie mówi nam o alumnach, którzy po tym okresie najprawdopodobniej kontynuowali naukę $w$ innych seminariach duchownych.

Należy pamiętać, że do Litomierzyc przyjeżdżali kandydaci z całej czeskiej części państwa czechosłowackiego, ponieważ jedynie tutaj istniała możliwość kształcenia przyszłych duchownych katolickich. Przebywanie na stosunkowo niewielkiej przestrzeni dużej liczby kleryków na pewno utrudniało codzienne funkcjonowanie i mogło budzić niepotrzebne napięcia związane z małą ilością miejsca. Plan dnia sprawiał, że przed przyszłym kapłanem stawiano wymagania, ale i usprawniano działanie w tych trudnych warunkach. Zwykły dzień tygodnia, od poniedziałku do soboty, wyglądał następująco: 6 - pobudka; 6.30 - poranne modlitwy, msza święta i śniadanie; 8.30 - zajęcia dydaktyczne; 10 - przerwa; 10.30 - zajęcia dydaktyczne; 12.10 lub 12.40 - obiad w zależności od rocznika i dnia tygodnia; 15 - zajęcia dydaktyczne; 16 - przerwa; 16.30 - zajęcia; 18 i 18.30 kolacja i rekreacja; 19.50 - czytania; 20.20 - modlitwy wieczorne; 21.30 - cisza nocna.

Niedziele wyglądały zupełnie inaczej - niezmienionym punktem była tylko pobudka. 6 - pobudka; 6.30 - poranna modlitwa, rozmyślanie i sprzątanie pokoi; 8 i 8.30 - próba śpiewu lub czytania; 8.40 - próba asysty; 9 - przygotowanie i przejście do katedry; 9.30 - msza święta $\mathrm{w}$ katedrze, powrót i plan własny, wszyscy według swojego programu; 11.20 - spotkanie w kaplicy, 
obiad dla I i V rocznika; 12 - spotkanie w kaplicy, obiad dla II i IV rocznika; 12.30 do 18.15 spacer przynajmniej we dwóch, nie można wracać wcześniej niż przed 16, czas wolny; 17 do 18.30 kolacja; 19 - modlitwy wieczorne i rekreacja; 20.45 - przygotowanie do snu; 21.15 - cisza nocna.

Pierwsi alumni z terenów Zaolzia pojawili się w Litomierzycach już w październiku 1953 roku. Było ich czterech, jednak już wcześniej studiowali, dlatego zaczęli od kolejnego, czwartego roku. Bruno Stoklasa urodzony w 1921 roku oraz Evzen Kalish urodzony w 1930 roku (obaj z Bogumina), Boleslav Chroboczek urodzony w 1929 roku w Suchej Górnej i Ervin Morcinek z Karwiny. Ostatecznie 27 czerwca 1954 roku zostali wyświęceni na księży. Kolejną osobą, która przewinęła się przez szeregi alumnów seminarium, był Jozef Vadovic, który studiów nie ukończył. Następnie na jednym roku znalazło się aż pięciu „rodaków”. Jozef Bury i Antonin Jachnicki urodzili się w Jabłonkowie, Jindrich Zagan w Czeskim Cieszynie, Jozef Byrtus w Bukowcu, a Ernest Dostal w Suchej Górnej. W 1958 roku wszyscy byli jeszcze na czwartym roku, a dwóch ostatnich zostało wyświęconych na diakonów. W międzyczasie przyjmowali święcenia niższe, czyli ostiariat, lektorat, egzorcystat, akolitat oraz wyższe - subdiakonat. Warto w tym miejscu wspomnieć, że w październiku 1956 roku studia rozpoczął Jan Dudys z Wędryni, a rok później Filip Byrtus. Obaj jednak uczyli się, aby zostać kapłanami w diecezji litomierzyckiej ${ }^{12}$.

$\mathrm{Na}$ początku nowej dekady, w 1960 roku, na kapłana został wyświęcony Edmund Kempny pochodzący z miejscowości Rzepiszcze. Na czwartym i dla siebie ostatnim roku był wówczas także Jindrich Lorizs z Wędryni. W następnym (1961) roku do grona kapłanów czechosłowackich dołączyło kolejnych dwóch kandydatów. Vaclav Dias pochodzący z Mistka oraz Zigmund Farnik z Cierlicka Górnego zaczęli swoją posługę na terenie czesko-cieszyńskiej Administratury Apostolskiej. W czerwcu 1962 roku na księdza został wyświęcony Stanislav Joachymek rodem z Jabłonkowa. Następny rok przedłużył tę tendencję i w czerwcu wyświęcono kolejnego kapłana - Oldricha Prachara z Ostrawy. Także w 1963 roku swoje studia rozpoczął Otto Gladis z Ostrawy, jednak już potem dokumenty seminaryjne nie odnotowują jego obecności. Podobnie Josef Jurasek długo nie zagościł na litomierzyckiej uczelni. Urodzony w Albrechcicach kleryk rozpoczął naukę w październiku 1963 roku, a już 24 maja

${ }^{12}$ Archiv Biskupství litoměřického (dalej: ABL), fond Catalogus Ordinandorum I, Korespondence: 1953-1956, 1956-1959. 
zrezygnował $\mathrm{z}$ dalszej edukacji na obranym kierunku${ }^{13}$. Przez kilka kolejnych lat kroniki nie mówią nam nic o następnych święceniach kapłańskich. Jako ciekawostkę należy dodać, że od roku 1964 w opisywanych dokumentach obok łaciny pojawia się również język czeski. W roku $1969 \mathrm{w}$ marcu wyświęcono na diakona Milana Adamka, jednak więcej informacji na jego temat nie ma ${ }^{14}$.

W tym roku warto odnotować obecność na wydziale studentów, którzy wcześniej skończyli jakąś kierunkową szkołę średnią lub nawet studiowali na wyższych uczelniach. Należy tu wspomnieć o Vaclavie Altrichterze, słuchaczu konserwatorium muzycznego, a jako ciekawostkę wymienić Josefa Benesa, który nie miał jeszcze zdanej matury. Obydwaj, wraz z Janem Prunorem oraz Vladislavem Skupniem z Nawsia, wstąpili do seminarium w 1968 roku, ale już w następnym roku dokumenty nic o nich nie wspominają. Po ukończeniu czterech semestrów teologii w Ołomuńcu zjawił się w Litomierzycach Alois Cienciała z Karwiny. Został on wyświęcony na diakona w 1970 roku wraz z Jirim Svanygą. Ich „rodak” Alois Kotek także trafił do seminarium w Litomierzycach po przerwanych studiach (sześć semestrów teologii w Ołomuńcu), jednak studiował dla diecezji ołomunieckiej. W roku 1975 odbyły się kolejne święcenia kapłańskie kandydata z czesko-cieszyńskiej Administratury Apostolskiej, a księdzem został Karel Macku. W międzyczasie przez litomierzyckie seminarium przewinęło się jeszcze dwóch diakonów: Antoni Szotkowski i Jan Eisner. Wreszcie w czerwcu 1978 roku święcenia kapłańskie otrzymał Rudolf Świenczek, który pochodził z Czeskiego Cieszyna.

To wydarzenie zamyka pewien etap w działalności seminarium, ponieważ każdy następny kleryk pochodzący z terenu Administratury Apostolskiej był automatycznie przypisywany do archidiecezji ołomunieckiej. Pierwszym takim okazał się pochodzący z Karwiny Josef Kaszper, który przyjął święcenia kapłańskie w 1979 roku w katedrze św. Wacława w Ołomuńcu. W dwa lata później według tej samej zasady księżmi zostali urodzony we Frydku Frantisek Vrubel oraz Vilem Kubatko z Karwiny. Na kolejne uroczystości związane z nowymi kapłanami omawianego regionu trzeba było czekać już tylko rok, a do stanu kapłańskiego dołączyli Vaclav Gandera i Vaclav Motyka, obaj z Czeskiego Cieszyna. Ostatecznie do końca istnienia Wydziału Teologicznego Kościoła Rzymskokatolickiego Cyryla i Metodego w Pradze w Litomierzycach wyświęcono jeszcze dwóch księży z dawnej Administratury Apostolskiej w Czeskim

\footnotetext{
${ }^{13} \mathrm{ABL}$, fond Catalogus Ordinandorum II, Kronika Seminare.

${ }^{14}$ Tamże, fond Catalogus Ordinandorum II, Korespondence.
} 
Cieszynie. Do stanu kapłańskiego wstąpili Alois Peroutka z Ostrawy-Zabrzegu w 1984 roku oraz Stanislav Zwyrtek z Mostów koło Jabłonkowa w 1986 roku. Do roku 1990 nie wyświęcono już żadnego księdza z omawianego obszaru. W połowie lat osiemdziesiątych klerykami byli pochodzący z Karwiny Pavel Stefan, Miroslav Seviola oraz Kamil Stefan, który przerwał studia po pierwszym roku. Warto jednak podkreślić stosunkowo dużą liczbę powołań, zwłaszcza w ostatnich latach istnienia wydziału. W październiku 1988 roku na pierwszym roku znalazło się aż dziewięciu kandydatów: Jan Szkandera, Pavel Kohut i Radim Byrtus z Trzyńca, Antonin Zolniercik z Witkowic, Martin Michut z Ostrawy, Marian Kuś z Frydka-Mistka oraz Roman Rylke, Tadeas Wojnar i kapucyn Frantisek Cinciala z Czeskiego Cieszyna. W tym samym czasie na drugim roku studiował jeszcze Josef Goryl z Trzyńca, a na trzecim Stefan Klocek z Karwiny i karmelita bosy Jan Wojnar. W ostatnim roku działalności wydziału na pierwszy rok dostali się Pavel Jaros i Richard Spirak z Karwiny ${ }^{15}$.

Jak już wspomniano, Kościół katolicki w Czechosłowacji był przez komunistyczne władze spychany na margines życia społecznego. Służyły temu także inne zabiegi, nie tylko zredukowanie liczby uczelni przygotowującej przyszłych kapłanów dla czeskiej części państwa do jednego. Nie można także zapomnieć, że studia $\mathrm{w}$ seminarium duchownym nie zwalniały z poboru do sił zbrojnych Czechosłowackiej Republiki Socjalistycznej. Zasadniczą służbę wojskową, która spowodowała przerwę w studiach, odbyło czterech późniejszych księży: Piotr Siostrzonek, Frantisek Vrubel, Alois Peroutka i Stanislav Zwyrtek ${ }^{16}$.

W latach 1953-1990 przez Wydział Teologiczny Kościoła Rzymskokatolickiego Cyryla i Metodego w Pradze w Litomierzycach przewinęło się 64 alumnów pochodzących z terenów czesko-cieszyńskiej Administratury Apostolskiej lub przeznaczonych do posługiwania $\mathrm{w}$ niej. Nie wszystkim dane było dotrzeć do końca edukacji. Na kapłanów zostało wyświęconych dziewiętnastu z nich, na uroczystej mszy świętej, którą w każdym roku celebrowano w sobotę pod koniec czerwca, zawsze w katedrze św. Wacława w Ołomuńcu o godzinie 9.30. Pięciu kandydatów pochodziło z omawianego terenu, jednak studiowali, aby posługiwać $\mathrm{w}$ innych diecezjach czeskich. Czterech $\mathrm{w}$ czasie nauki musiało zameldować się w czechosłowackim wojsku, aby spełnić obywatelski obowiązek służby socjalistycznej ojczyźnie. W roku 1990 przygotowywanie i kształcenie kleryków przeniesiono do stolic poszczególnych diecezji, a seminarium

\footnotetext{
${ }_{15}$ Tamże, fond XV Seznamy a adresy bohoslovcu a zamestancu.

${ }_{16}$ Tamże, fond I Evidence natistenych skrypt 1970-89.
} 
duchowne dla dawnej Administratury Apostolskiej w Czeskim Cieszynie, w której skład wchodziło Zaolzie, zostało odtworzone w Ołomuńcu ${ }^{17}$.

\section{Streszczenie}

Klerycy z Administratury Apostolskiej w Czeskim Cieszynie studiujący na Wydziale Teologicznym Cyryla i Metodego w Pradze

Administratura Apostolska w Czeskim Cieszynie nierozerwalnie łączy się z historią Śląska Cieszyńskiego oraz Polaków, którzy jako mniejszość narodowa znaleźli się poza granicami własnej ojczyzny. Dzieje tej struktury administracyjnej obrazują także skomplikowane losy Kościoła katolickiego w Czechosłowacji pod wpływami rządów komunistycznych w trudnym dla niego okresie po II wojnie światowej.

Śląsk Cieszyński jest to region na granicy polsko-czeskiej, podzielony obecnie wzdłuż rzeki Olzy. Początkowo należał do Polski, następnie do Królestwa Czech, a po I wojnie światowej stał się obiektem sporu między nowo powstałymi państwami: Polską i Czechosłowacją. Rejon ten zamieszkiwali w większości Polacy, a po podziale w 1920 roku duża ich część znalazła się po zachodniej stronie rzeki Olzy. Obszar ten z czasem zaczęto nazywać Zaolziem.

Kościół katolicki na tym terenie należał do diecezji wrocławskiej. Po II wojnie światowej w 1947 roku powstała Administratura Apostolska w Czeskim Cieszynie, która istniała do roku 1978, aż została oficjalnie włączona do archidiecezji ołomunieckiej. Większą część obszaru tej struktury zajmowało Zaolzie zamieszkałe początkowo w większości przez Polaków.

Od roku 1953 do 1990 wszyscy klerycy z tej części Czechosłowacji kształcili się oficjalnie w Wyższym Seminarium Duchownym w Litomierzycach. Przyjeżdżali tam również klerycy z tzw. Administratury Apostolskiej w Czeskim Cieszynie. Wielu z nich wywodziło się z polskiej mniejszości Zaolzia. Część deklarowała się jako Czesi, część jako Polacy. $\mathrm{W}$ dokumentach litomierzyckiej uczelni możemy odnaleźć alumnów z nazwiskami polsko brzmiącymi lub po prostu czeskimi. Większość z nich urodziła się jednak na terenie Zaolzia.

${ }^{17}$ V. Novotny, Katolicka..., s. 309. 


\section{Słowa kluczowe}

Zaolzie, Śląsk Cieszyński, seminarium, klerycy, Litomierzyce, Administratura Apostolska

\section{Summary}

\section{Clerics from Apostolic Administration in the Czeski Cieszyn studying at the Catholic Theological Faculty of St. Cyril and Methodius in Prague}

Apostolic Administration in the Czeski Cieszyn is inextricably linked with the history of Cieszyn Silesia and the Polish community, which found themselves as a minority beyond the borders of their own country. History of this administrative structure also illustrates the complicated fate of the Catholic Church in Czechoslovakia under the influence of communist authority in the difficult period after World War II.

Cieszyn Silesia is a region on the Polish-Czech border, currently divided along the river Olza. Originally belonged to the Poland, then to the Kingdom of Bohemia and after World War I became the object of a strife between the fledging states Poland and Czechoslovakia. This region was inhabited by the majority of Poles and many of them found themselves outside their homeland. Area on the west side of Olza river began to be called Zaolzie.

The Catholic Church in this territory belonged to the diocese of Wroclaw. After World War II in 1947, the Apostolic Administration was established in the Czeski Cieszyn. It existed to 1978, when was officially incorporated into the Archdiocese of Olomouc. Zaolzie took the greater part of the area of this structure and was originally inhabited mostly by Poles.

From 1953 to 1990, all clerics from this part of Czechoslovakia formally educated in the only official seminary in Litomierzyce. Students from Apostolic Administration in the Czech Cieszyn also came there. Many of them descended from the Polish minority in Zaolzie. Some declared as Czechs, the other as Poles. In documents of seminary in Litomierzyce we can find clerics with Polish-sounding or just Czech surnames. Most of them, however, were born in Zaolzie.

\section{Keywords}

Zaolzie, Cieszyn Silesia, seminary, clerics, Litomierzyce, Apostolic Administration 


\section{Bibliografia}

\section{Źródła archiwalne}

Archiv Biskupství litoměřického

Kněžský seminář

Catalogus Ordinandorum I, Korespondence: 1953-1956, 1956-1959.

Catalogus Ordinandorum II, Kronika Seminare.

Catalogus Ordinandorum II, Korespondence.

Źródła drukowane

Codex Iuris Canonici. Romae 1917.

Opracowania

Balik S., Hanus J., Katolicka Cirkev na Ceskoslovensku 1945-1989. Brno 2007.

Kuś J., Szkice z dziejów kościelnych Śląska Cieszyńskiego. Kraków 1983.

Londzin J., Historja Generalnego Wikarjatu w Cieszynie. Cieszyn 1926.

Novotny V., Katolicka Teologicka Fakulta 1939-1990. Praha 2007.

Roszkowski W., Najnowsza historia Polski 1914-1945. Warszawa 2003.

Gąsior G., Zaolzie. W: Zaolzie. Polsko-czeski spór o Śląsk Cieszyński 1918-20o8, Warszawa 2008, s. 2-10.

Zbranek T., Apoštolský administrátor František Borgiáš Onderek. W: Sborník Státního okresního archivu Frýdek-Místek, Frydek-Mistek 2011, s. 104-111. 
